\title{
衝撃荷重を受ける燃料棒の座屈に関する数値解析*
}

\author{
感本広文*1，安田隆芳*2，中司雅文*2，河村庄造*1
}

\section{Numerical Study on the Buckling of Fuel Rods under Impact Loads}

\author{
Hirofumi MINAMOTO*1 ${ }^{*}$ TakayoshiYASUDA, Masafumi NAKATSUKA \\ and Shozo KAWAMURA \\ ${ }^{* 1}$ Department of Mechanical Engineering, Toyohashi University of Technology \\ 1-1 Hibarigaoka Tenpaku-cho, Toyohashi, Aichi, 441-8580 Japan
}

\begin{abstract}
Nuclear fuel assembly is installed in the cask with the necessary protective function during fuel transportation. The structural integrity of the fuel rods which constitutes fuel assembly has to be evaluated to ensure the safety even for the cask vertical drop accident. The buckling behavior of thin shell tubes by an impact weight have already studied by many researchers experimentally and numerically. However the experiments of irradiated fuel cladding tubes accompany many of difficulties and the number of the experiment is limited. The authors have derived the constitutive relation of the irradiated fuel cladding material, Zircaloy-2, in the previous work and have studied the influences of material properties on the buckling behavior of irradiated fuel cladding tube under the cask drop incident by using finite element simulation code, LS-DYNA. The purpose of this paper is to elucidate the effect of impact velocities, impact mass, boundary conditions and eccentricity of the impact point on the dynamic buckling behavior of the irradiated cladding tube. It is found that the larger impact velocities under the same mass and the smaller impact mass under the same impact energy induce the larger load. The boundary conditions and eccentricities of the impact point have not affected the dynamic buckling load and absorbed energy. However, the deformed shape of the cladding tube is changed largely by the boundary condition. It is also found that the Euler buckling load has possibility to underestimate the dynamic buckling load of the cladding fuel rods.
\end{abstract}

Key Words : Buckling, Dynamic Buckling Load, Impact Strength, Nuclear Fuel Rods, Cladding Tube, Finite Element Method, Computational Mechanics

\section{1. 緒言}

使用済みの原子燃料はキャスクと呼ばれる密封容器に収納され，貯蔵施設において所定期間貯蔵される．各施 設間の燃料の輸送においてはクレーンでのキャスク吊り下げ工程があり，万一落下事故等が発生しても放射性物 質が放出しないように，かつ経済的に優れた燃料集合体の取り扱い技術の確立に向けて，事故時の健全性および 設計に対する裕度を予測することが重要な研究課題になっている(1).

使用済みの原子燃料を用いた実験には多くの困難を伴うため, 数值解析による予測が有力な手段となり，例え ば燃料棒全長を被覆管と燃料ペレットからなる要素にモデル化し，負荷荷重の時間依存性を入力して，落下時の 破損限界座屈荷重を求め, 非弾性円柱理論の解と比較した研究(2)や, 梁理論に基づいて燃料ペレットの有無に対 応した座屈限界加速度を予測した研究(3)，さらに燃料棒全長およびスペーサを含む燃料集合体全体を有限要素で モデル化して落下時の燃料棒に生じるひずみ量に及ぼすペレットの寄与の重要性を示した研究(4)がある.また， 沸騰水型原子炉（Boiling Water Reactor:BWR）燃料集合体がプール中の取り扱いミスでプール底に衝突した場 合の応力を解析した研究(5)等があり, 個々の事例毎の安全性が示されている.

\footnotetext{
*原稿受付 2011 年 4 月 8 日

${ }^{* 1}$ 正員, 豊橋技術科学大学大学院工学研究科（广441-8580 愛知県豊橋市天伯町字雲雀ヶ丘 1-1）

*2 日本核然料開発(株)（广311-1313 茨城県東茨城郡大洗町成田町 2163 番地）

E-mail: minamoto@me.tut.ac.jp
} 
一般に燃料被覆管には薄肉の細長円管が使用されているが，一般構造物としての薄肉円管の衝撃座屈について は，これまでに実験的ならびに数值的に多くの研究がなされている ${ }^{(7)}$. 例えば, 数值計算 ${ }^{(8),(9),(10)}$ ならびに実験と 計算の両方(11),(12)によって境界条件，衝突速度が座屈モードの遷移におよぼす影響を調べた研究，また，実験およ び計算で管の肉厚が座屈モードに及ぼす影響を調べた研究(13)などがある。これらの研究は，主として一般的な構 造材料であるアルミニウム合金やSteel 等を対象として行われているが，燃料棒の材料特性を考慮した検討は少 ないようである，燃料棒はジルカロイ合金製であり，原子炉内での使用により中性子照射の影響を受けるため， これらの材料特性を考慮した検討が必要である.

著者らは先に高燃焼度（中性子照射量 : $1.5 \times 10^{26} \quad 1 / \mathrm{m}^{2}, \mathrm{E}>1 \mathrm{MeV}$ ）まで使用された燃料被覆管の低ひずみ 速度から衝撃負荷相当のひずみ速度範囲に対する室温での構成方程式を求めた ${ }^{(14)}$. そこで, 本論文では既報で導 出した燃料棒被覆管の材料特性を用いて, キャスク落下時の燃料棒の座屈挙動に及ぼす衝撃速度, 衝突体質量, 端部境界条件，打撃点偏心量の影響を調べる事を目的とする. 燃料集合体を構成する燃料棒単体の代表的な区間 に着目して，燃料被覆管にキャスク落下時相当の垂直衝撃荷重が作用した場合を基準として，上記諸条件を変化 させて被覆管の動的応答を有限要素法によって解析する. 得られた数值解析結果より, 各条件が座屈荷重, 被覆 管変位，吸収エネルギー等に及ぼす影響を調べる，そして最後に動的座屈荷重の検討，被覆管の破壊について検 討を加える。

\section{2. 被覆管の構成方程式}

被覆管材料は製造時の圧延変形によって異方性を有しているが，それは原子炉内での中性子照射により緩和さ れる傾向にある(15),(16)．よって，被覆管材料の弾性および塑性挙動は等方性として扱う．また，中性子照射が弾性

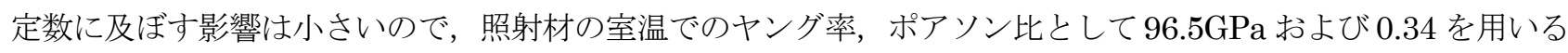
(17)。また，密度は $6510 \mathrm{~kg} / \mathrm{m}^{3}$ とした ${ }^{(17)}$ ，応力-ひずみ関係は降伏応力および接線剛性からなる bi-linear で近似 する．接線剛性は $\mathrm{E}_{\mathrm{t}}=1640 \mathrm{MPa}$ とした ${ }^{(14)}$.

降伏応力は，中性子照射量およびひずみ速度の関数として式(1)の Cowper-Symonds model ${ }^{(7)}$ で表わされる ${ }^{(14)}$.

$$
\sigma_{\mathrm{y}}(\phi \mathrm{t}, \dot{\varepsilon})=\sigma_{\mathrm{i}}(\phi \mathrm{t})\left[1+\left(\frac{\dot{\varepsilon}}{3.091 \times 10^{5}}\right)^{1 / 7.949}\right]
$$

ここで， $\sigma_{\mathrm{y}}(\phi \mathrm{t}, \dot{\varepsilon})$ は，中性子照射量 $\phi \mathrm{t}$ および，ひずみ速度 $\dot{\varepsilon}\left(\mathrm{s}^{-1}\right)$ による変化を考慮した降伏応力， $\sigma_{\mathrm{i}}(\phi \mathrm{t})$ は標準的な試験方法に準拠したひずみ速度 $\left(8.3 \times 10^{-5} \mathrm{~s}^{-1}\right)$ での中性子照射量（1/ $\mathrm{m}^{2}$, 中性子エネルギー $\mathrm{E}$ $>1 \mathrm{MeV})$ に依存する降伏灾力であり, 以下の実験式(18)で求められる.

$$
\sigma_{\mathrm{i}}(\phi \mathrm{t})=\sigma_{0}\left\{1+0.910\left(\frac{\phi \mathrm{t}}{10^{24}}\right)^{0.071}\right\}
$$

ここで，，0 0 は室温 $(298 \mathrm{~K})$ における未照射材の降伏応力であり $\sigma_{0}=380 \mathrm{MPa}$ である(18). 以上の材料定数をもとに高燃焼度（中性子照射量 : $1.5 \times 10^{26} 1 / \mathrm{m}^{2}, \mathrm{E}>1 \mathrm{MeV}$ ）まで使用された燃料被覆管

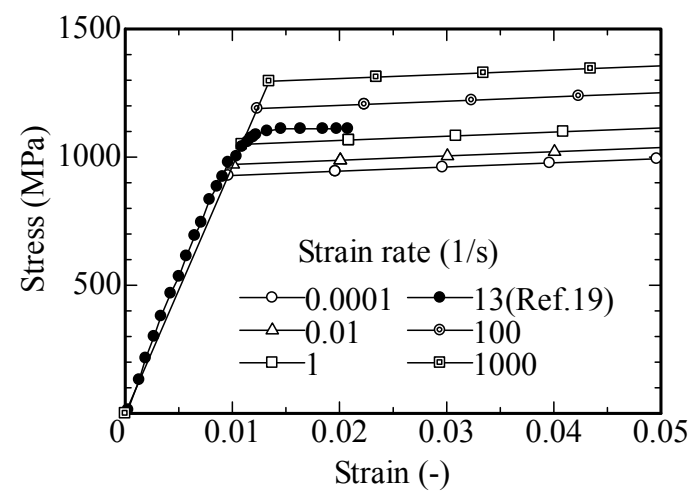

Fig.1 Stress strain relations of high burnup fuel cladding tube at room temperature and comparison with experimental data in Ref.(19) 
の低ひずみ速度から衝撃負荷相当のひずみ速度範囲 $\left(1 \times 10^{-4} \sim 10^{3} \mathrm{~s}^{-1}\right)$ に対する応力-ひずみ関係を求めた結果を 図 1 に示寸．図 1 中の○プロットは同等の中性子照射（中性子照射量： $1.2 \times 10^{26} \quad 1 / \mathrm{m}^{2}, \mathrm{E}>1 \mathrm{MeV}$ ）を受けた 使用済夕被覆管の高速（ひずみ速度約 $13 \mathrm{~s}^{-1}$ ) 引張り試駼結果 ${ }^{(19)}$ である. 図を見ると，本構成式は照射材の応力一 ひずみ関係を妥当に近似していると考えられる，高然焼度まで使用された被覆管の破断限界については，十分な 数の実験データがなく, 試験方法や試験温度および腐食の程度によっても異なる. しかしながら，一般に炉内で の燃焼によって延性は低下し, 限られた既存の実駼結果から破断伸びは 3〜8\%程度であると推定される ${ }^{(18),(19),(20)}$.

\section{3. 数 值 解 析}

\section{$3 \cdot 1$ 解析対象および仮定}

使用済みの軽水炉燃料集合体がキャスク中もしくはプール中のクレーン誤動作等で垂直落下寸る場合に衝撃 荷重を受ける事象を想定する.例として BWR 燃料集合体の構成および外観図と衝撃状況を概念的に図 2 に示す. 燃料棒は細径の円筒である燃料被覆管に $\mathrm{UO}_{2}$ からなる燃料ペレットが挿入され, 管両端部に端栓を密封溶接して 構成されている. 燃料棒の下部端栓は支持板（下部タイプレート）に挿入して固定し, 約 $500 \mathrm{~mm}$ 毎にスペーサ を介して燃料棒の間隔を保持している.したがって, 燃料集合体に衝突力が作用したときの燃料棒の挙動は, 被 覆管と燃料ペレットとの固着状態，衝突力の作用点等の不確定因子の影響を受ける.

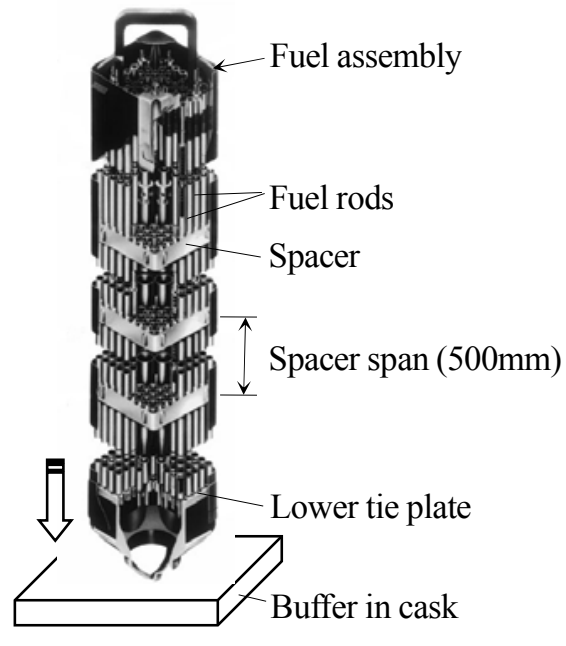

Fig.2 Conceptual representation of the fuel assembly in the cask under cask drop accident

燃料棒全体の挙動には種々の因子が入り複雑であるので，まず個別因子の影響を明らかにする．本来は 1 本の 燃料棒全体を有限要素でモデル化し，それがキャスク内壁に衝突する解析を行う必要がある。しかしながら，こ こでは燃料被覆管の健全性に注目して被覆管の基本的な動的応答を検討するために, 計算容量等の観点から以下 の仮定(1)〜 (4)を採用し，燃料棒の最下部 $500 \mathrm{~mm}$ 間に，燃料棒の衝突と同じ初期運動エネルギーを有する衝突体 を衝突させて解析を行った.

(1)燃料集合体を構成する燃料棒は，全て同等の振る舞いをすると仮定して，1本の燃料棒を解析対象にする.

(2)燃料棒は原子炉内で中性子照射を受けたジルカロイ-2 製の細管（外径約 $12.3 \mathrm{~mm}$ ，内径約 $10.6 \mathrm{~mm}$ ，長さ約 4000mm）であるが，このうち下部タイプレートと最下端のスペーサ間の $500 \mathrm{~mm}$ を解析対象にする.

(3)解析対象の被覆管は真直な管であり，燃料ペレットの剛性の影響は含めないものとする.

(4)集合体落下時の障壁との衝突による衝撃荷重として, 燃料ペレットを含む燃料棒 1 本の全質量（3.5kg）が, 被覆管の片端に作用寸るとし, 他端は質量および岡性が十分大きい受け台で変位が拘束されているものとする.

\section{$3 \cdot 2$ 解析対象の幾何学体系}


以上の仮定から，本研究で扱う解析対象物の幾何学的な体系は図 3 のようになる. 図 2 に示される燃料棒の最 下端（落下時に衝撃荷重が発生する位置）は，図 3 では上端に示されている. 図中の L は解析対象とする被覆管 の長さ（L=500mm）を表す.

\section{$3 \cdot 3$ 数值解析手法と有限要素モデル}

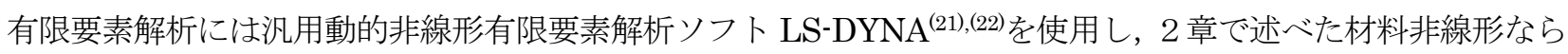
びに幾何学的非線形を考慮する. 材料モデルには汎用性に優れる Piecewise Linear Isotropic Plasticity モデルを 採用し，降伏判定にはミーゼスの降伏条件を用いた。式(1)に示した Cowper-Symonds modelによって，降伏応 力の中性子照射量ならびにひずみ速度に対する依存性を考慮した，なお，中性子照射量は原子炉で高燃焼度まで 使用された燃料被覆管の代表的な值として, $1.5 \times 10^{26} 1 / \mathrm{m}^{2}, \mathrm{E}>1 \mathrm{MeV}$ とした.

被覆管は 8 節点 SOLID 要素でモデル化し，予備計算から解の精度と経済性を共に満たす条件として長手軸方 向 300 分割, 円周方向 48 分割, 肉厚方向 3 分割とした $(1$ 要素 $\fallingdotseq 1.7 \times 0.7 \times 0.24 \mathrm{~mm})$ ．上端に作用する燃料棒 の質量 $(3.5 \mathrm{~kg})$ は剛体要素でモデル化した。剛体要素と被覆管上端の接触計算にはペナルティ法を用いた．有限要 素モデルを図 4 に示寸．なお，本有限要素モデルは弾性応力波の伝播挙動を適切にシミュレートできている事を 既報 ${ }^{(14)}$ において確認済である。一連の計算には豊橋技術科学大学情報基盤メディアセンターならびに京都大学学 術情報メディアセンターの計算機を使用した.

\section{$3 \cdot 4$ 解析条件}

上で説明した解析手法によって, 衝撃速度, 重錐質量, 端部境界条件, 打撃中心の偏心量をパラメータとして 衝撃圧縮を受ける燃料棒被覆管の数值解析を行う.

衝撃速度は燃料集合体落下時の吊り下げ高さによって変化するが，ここでは燃料集合体の解析事例を参考にし て，代表的な值として $15 \mathrm{~m} / \mathrm{s}$ を基準として， $5 \mathrm{~m} / \mathrm{s} \sim 20 \mathrm{~m} / \mathrm{s}$ の範囲で解析を行う（Case1〜4）.

次に, 重鍾質量 $3.5 \mathrm{~kg}$, 衝撃速度 $15 \mathrm{~m} / \mathrm{s}$ の場合(Case3)を基準として, 重錘の初期運動エネルギーが同じになる 衝撃速度について重錐質量 $1.75 \mathrm{~kg}$ （Case5）ならびに重錐質量 7kg（Case6）の解析を行う（衝撃速度は Case5： $21.2 \mathrm{~m} / \mathrm{s}$, Case $6: 10.6 \mathrm{~m} / \mathrm{s})$.

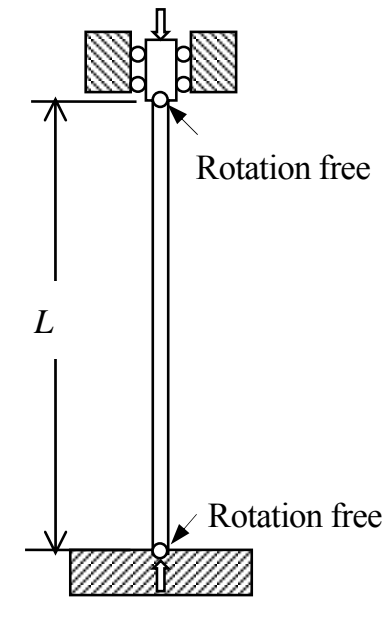

Fig.3 Geometrical description for numerical analysis

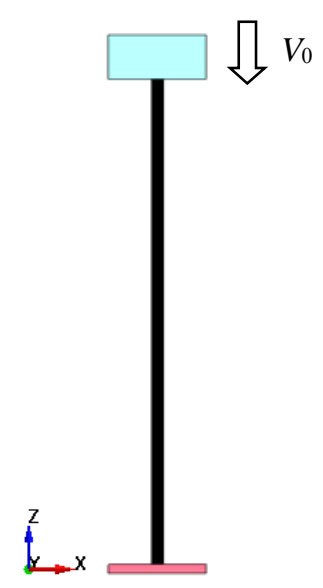

(a)

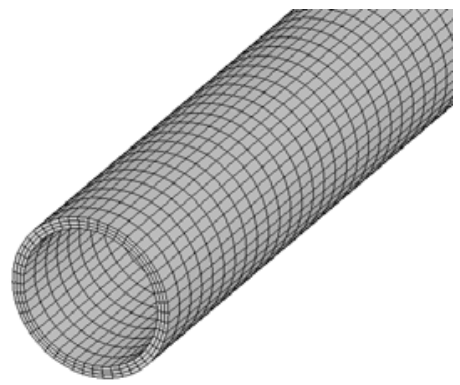

(b)

Fig.4 Finite element mesh used in the simulations

また, 被覆管上端はスペーサで保持されている事から, 図 3 に示される横方向変位拘束 ・回転自由 (Pin, Case3) を基準として，横方向変位と回転を拘束した場合（Fix，Case7）および無拘束の場合（Free，Case8）につい て解析を行う.

以上のシミュレーションでは, 文献(4),(9)に解析例を参考にして, 衝突体の重心と被覆管中心に $0.2 \mathrm{~mm}$ の偏心 をあたえて解析を行う。これは, シミュレーション上で座屈挙動を誘起するための初期不整として導入したもの 
であるが，現実の衝突事象ならびに実験においても，打撃点の偏心は避け難いものと思われる，そこで，打撃点 の偏心量が $1 \mathrm{~mm}$ (Case9)，および $2 \mathrm{~mm}$ （Case10）の場合について解析を行った.

以上で設定した解析ケース(Case1〜10)を表 1 にまとめた.

Table 1 Simulation cases

\begin{tabular}{|c|c|c|c|c|c|c|c|c|c|c|c|c|c|}
\hline \multirow{2}{*}{$\begin{array}{l}\text { Case } \\
\text { No. }\end{array}$} & \multicolumn{4}{|c|}{ Impact speed $(\mathrm{m} / \mathrm{s})$} & \multicolumn{3}{|c|}{ Mass (kg) } & \multicolumn{3}{|c|}{ Boundary condition } & \multicolumn{3}{|c|}{ Eccentricity $(\mathrm{mm})$} \\
\hline & 5 & 10 & 15 & 20 & 1.75 & 3.5 & 7 & Pin & Fix & Free & 0.2 & 1 & 2 \\
\hline 1 & 0 & & & & & 0 & & 0 & & & 0 & & \\
\hline 2 & & 0 & & & & 0 & & 0 & & & 0 & & \\
\hline 3 & & & 0 & & & 0 & & 0 & & & 0 & & \\
\hline 4 & & & & 0 & & 0 & & $\bigcirc$ & & & 0 & & \\
\hline 5 & & & & 21.2 & 0 & & & 0 & & & 0 & & \\
\hline 6 & & 10.6 & & & & & 0 & $\bigcirc$ & & & 0 & & \\
\hline 7 & & & 0 & & & 0 & & & 0 & & $\bigcirc$ & & \\
\hline 8 & & & $\bigcirc$ & & & $\bigcirc$ & & & & 0 & $\bigcirc$ & & \\
\hline 9 & & & 0 & & & 0 & & 0 & & & & 0 & \\
\hline 10 & & & 0 & & & 0 & & 0 & & & & & 0 \\
\hline
\end{tabular}

\section{4. 結果と考察}

以下の各節で表 1 に示された各解析ケースで得られた結果を示し, 衝撃速度を変化させた場合, 初期運動エネルギー を同じとして衝突体（重錘）質量を変化させた場合，管上端境界条件，打撃点偏心量の影響について検討する．そし て, 得られた動的座屈荷重とオイラーの座屈荷重を比較すると共に, 被覆管に破壊条件を与えた場合の計算結果を示す.

\section{$4 \cdot 1$ 衝撃速度の影響（Case 1 4）}

図 $5(\mathrm{a})$ に衝撃荷重の時間的変化，図 $5(\mathrm{~b})$ に重錐変位の時間的変化，図 $5(\mathrm{c})$ に吸収エネルギーの時間的変化 を示す. 衝撃開始時を $\mathrm{t}=0$ として, 荷重は重錐加速度に重錐質量を乗じて求め, 吸収エネルギーは被覆管の内部 エネルギー（ひずみエネルギー）を表示している，また，図５（a），図５（b)から時間を消去した荷重一変位線図 を図 $5(\mathrm{~d})$ に示す（ただし，変位は重錘の下方への変位を正とした）.

図 6 は $\mathrm{t}=0.0015 \mathrm{~s}$ における被覆管の変形形状と相当塑性ひずみの分布を示したものである．同図（a ），（b ）, （c）にそれぞれ衝撃速度 $10 \mathrm{~m} / \mathrm{s} ， 15 \mathrm{~m} / \mathrm{s} ， 20 \mathrm{~m} / \mathrm{s}$ の場合を示す.

図 5(a)，(c)より，衝撃速度が速くなるほど最大荷重ならびに吸収エネルギーが増加していることが分かる。

図 $5(\mathrm{a}) ，(\mathrm{~d})$ に示されるように，衝撃速度 $5 \mathrm{~m} / \mathrm{s}$ （約 $1.3 \mathrm{~m}$ からの自由落下式による値）の場合は弾性衝突と なった. 図 5(a)の荷重変化に重畳する振動波形は，弾性応力波の伝播によるものであり，この波の周期は弾性 応力波の往復時間（ $t=2 \mathrm{~L} / \mathrm{c}=0.26 \mathrm{~ms}, \mathrm{c}$ 弾性縦波の伝播速度）に等しい. 塑性変形を生じていないので吸収エネ ルギーは微小である(弾性振動のみ)。

図 5 ( a )に示されるように, 衝撃速度 $15 \mathrm{~m} / \mathrm{s}$ では, $\mathrm{t}=0.52 \mathrm{~ms}$ 付近で応力波伝播による振動の重畳がなくなって いるため, 応力波は 2 往復した後で消滅した事が分かる，その後，衝撃荷重はしばらく一定值を保ち，管全長に 塑性変形を生じながら，図 $6(\mathrm{~b})$ に示されるように数箇所で管側部にひずみの集中部を形成し，座屈後は荷重が 急減している，この時，図 $5(\mathrm{~d})$ に示されるように，荷重がほぼ変位一定で急落した後は，荷重值に変動を伴い ながらわずかに弾性回復を生じている.

図 6( a )に示されるように，衝撃速度 $10 \mathrm{~m} / \mathrm{s}$ の場合は $15 \mathrm{~m} / \mathrm{s}$ の場合（図 6(b)）と異なり，管の下端部で塑性 ひずみの高い領域が生じており，他の部分にはひずみの集中がみられない. そして，図 5 ( a )に示されるように, 衝撃速度 $15 \mathrm{~m} / \mathrm{s}$ の場合と同様に応力波は途中で消滅するが，荷重は一定值を保持せず漸減する．また，図 $6(\mathrm{~d})$ 
に示されるように, 座屈発生後は衝撃速度 $5 \mathrm{~m} / \mathrm{s}$ の場合と同様な弾性回復を示している.よって, 衝撃速度 $10 \mathrm{~m} / \mathrm{s}$ の場合は, $5 \mathrm{~m} / \mathrm{s}$ と $15 \mathrm{~m} / \mathrm{s}$ の場合の中間的な挙動を示していると考えられる.

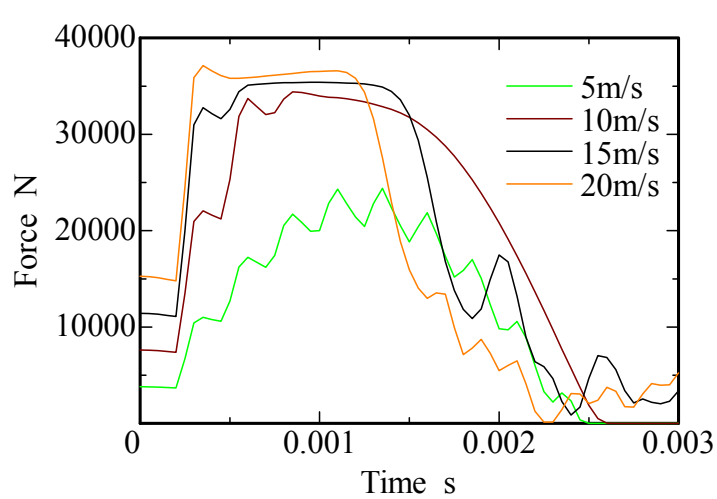

Fig.5(a) Variation of force with time

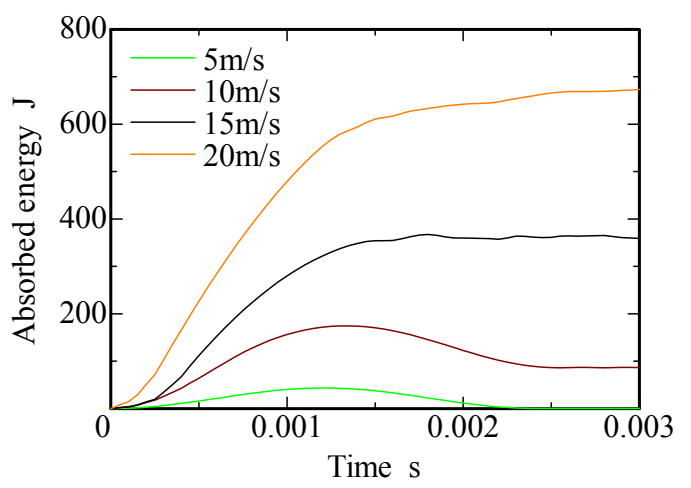

Fig.5(c) Variation of absorbed energy with time

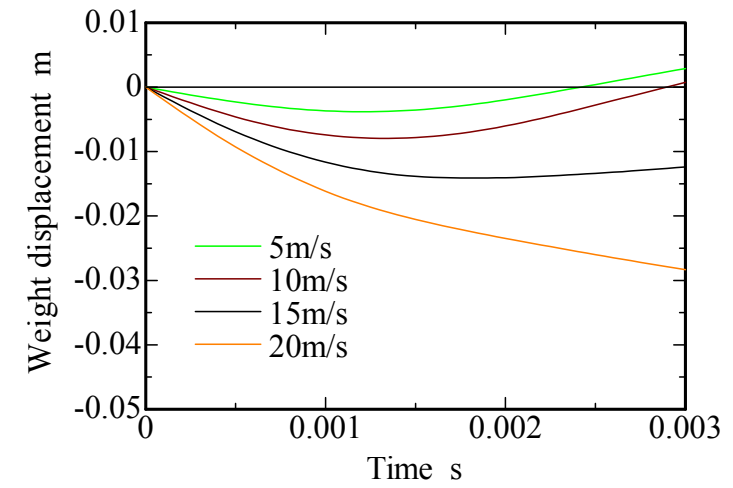

Fig.5(b) Variation of displacement with time

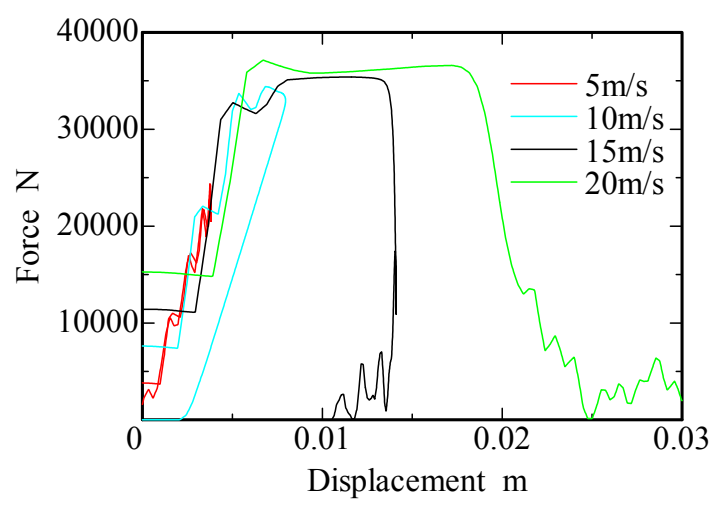

Fig.5(d) Force-displacement diagram

Fig.5 Influence of impact velocity (Case1,2,3,4)

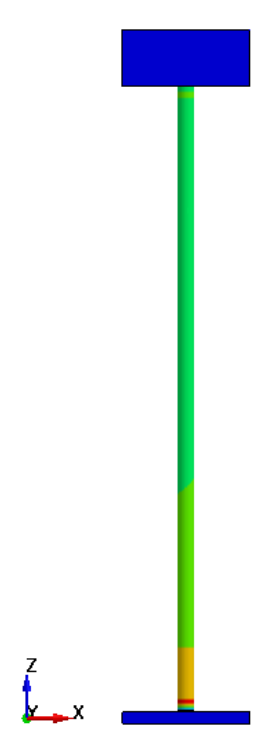

(a) Case $2: 10 \mathrm{~m} / \mathrm{s}$

$$
\begin{gathered}
\text { Fringe Levels } \\
1.020 \mathrm{e}-02 \\
8.496 \mathrm{e}-03 \\
6.797 \mathrm{e}-03 \\
5.098 \mathrm{e}-03 \\
3.398 \mathrm{e}-03 \\
1.699 \mathrm{e}-03 \\
0.000 \mathrm{e}+00
\end{gathered}
$$

Fringe Levels

Fringe Levels

$3.199 \mathrm{e}-02$

$2.666 \mathrm{e}-02$

$2.133 \mathrm{e}-02$

$1.600 \mathrm{e}-02$

$1.066 \mathrm{e}-02$

$5.332 \mathrm{e}-03$

$0.000 \mathrm{e}+00$

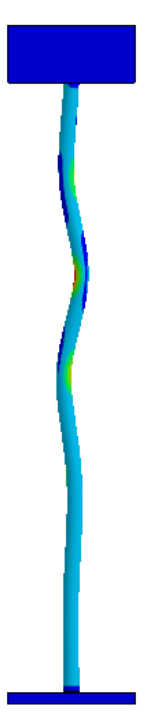

$1.347 \mathrm{e}-01$

1.122e-01_

$8.978 \mathrm{e}-02$

$6.734 \mathrm{e}-02$

$4.489 \mathrm{e}-02$

$2.245 \mathrm{e}-02$

$0.000 \mathrm{e}+00$

(c) Case $4: 20 \mathrm{~m} / \mathrm{s}$

Fig.6 Deformation shape and distribution of effective plastic strain $\quad(t=0.0015 \mathrm{~s})$ 
図 5 ( a )の衝撃速度 $20 \mathrm{~m} / \mathrm{s}$ の場合に見られる明確な応力波は 1 波（ 1 往復）のみである. 衝撃速度 $15 \mathrm{~m} / \mathrm{s}$ と $20 \mathrm{~m} / \mathrm{s}$ の場合は, 応力波が 1 往復 $(\mathrm{t}=0.26 \mathrm{~ms})$ した後に, 管の端部に塑性変形を生じ, 荷重が急激に上昇する ${ }^{(14)}$. $20 \mathrm{~m} / \mathrm{s}$ の場合は $15 \mathrm{~m} / \mathrm{s}$ の場合に比べて一定荷重の時間は短いが (図 $5(\mathrm{a})$ ), 変位に対する変化でみると (図 $5(\mathrm{~d})$ ), 一定荷重の期間が長く，短時間で大きな変位を生じている事が分かる．また，図 6 ( c) に示されるように，横方 向変位も顕著となる. ゆえに，20m/s の場合は他の場合に比べて吸収エネルギーが最も大きくなっている（図 5 (b)).

上記より，衝撃速度が速いほど応力波の減衰が早く，また，衝撃速度が速いほど座屈の出現（荷重の減少）が 早い事が分かる．これは衝撃速度が速いほど発生する弾性応力波の応力值が大きくなるため, 降伏の発生が早く なるためであると考えられる.

\section{2 衝突体質量の影響 (Case 3,5,6)}

図 $7(\mathrm{a})$ に衝撃荷重の時間的変化，図 $7(\mathrm{~b})$ に重錘上下方向変位の時間的変化，図 $7(\mathrm{c})$ に吸収エネルギーの時 間的変化，図 $7(\mathrm{~d})$ に荷重一変位線図を（重錘変位は下方を正）を示す.

図 8 は $\mathrm{t}=0.0015 \mathrm{~s}$ での被覆管変形形状と相当塑性ひずみ分布を示したものである.同図 $(\mathrm{a})$ ，（b)にそれぞれ重 錘質量 $1.75 \mathrm{~kg}$ (Case5)，7kg（Case6）の場合を示す。なお，重錘質量 $3.5 \mathrm{~kg}$ （Case3）の場合は，図6（b）に既 出である.

図 7 ( a ), ( b )より，重錘の初期運動エネルギーが同じ場合，重錘質量が増加すると最大荷重は減少し，重錘の 下方への変位が増加している事が分かる. しかし，重錘質量が大きい場合は重錘の下方への最大変位が大きく， 荷重の作用時間が長いため, 最終的な吸収エネルギーは大きくなっている (図 7 ( c c)).

図 7 ( a )の重錘質量 $1.75 \mathrm{~kg}$ の場合に見られる明確な応力波は 1 波（1 往復）のみであり，その後しばらく一定 荷重を保ち，ひずみ集中部が形成され座屈変形が顕在化（図 8 ( a ) ) するに伴い荷重が急減している。一方，重 錘質量が $3.5 \mathrm{~kg}$ および $7 \mathrm{~kg}$ の場合は応力波が 2 往復後に消滅している.よって，重錘質量が小さいほど応力波の 減衰が早い事がわかる.

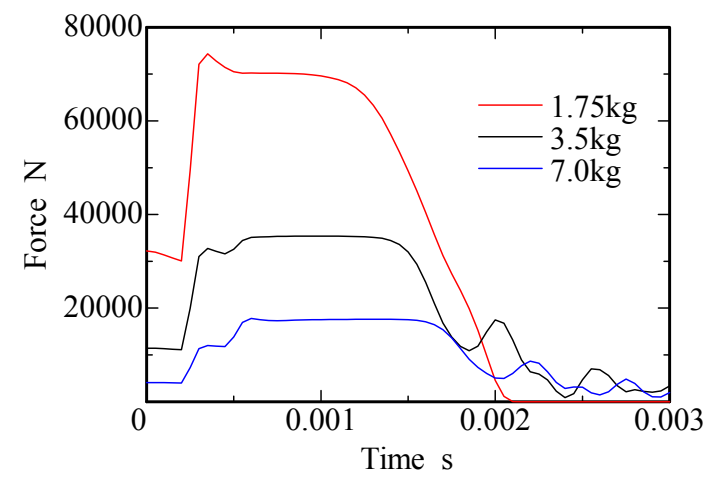

Fig.7(a) Variation of force with time

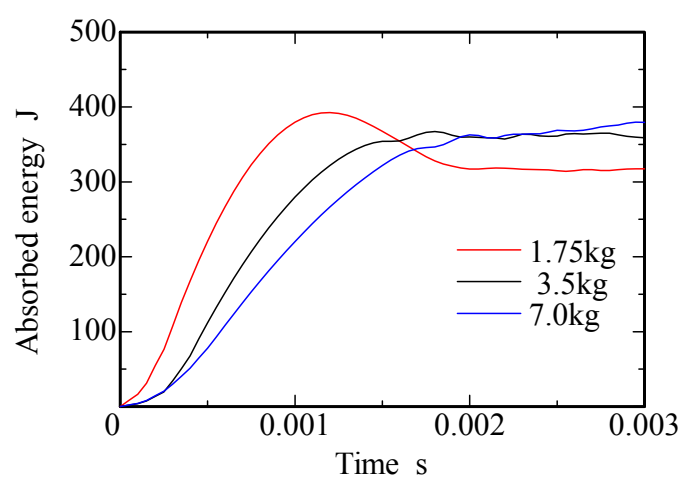

Fig.7(c) Variation of absorbed energy with time

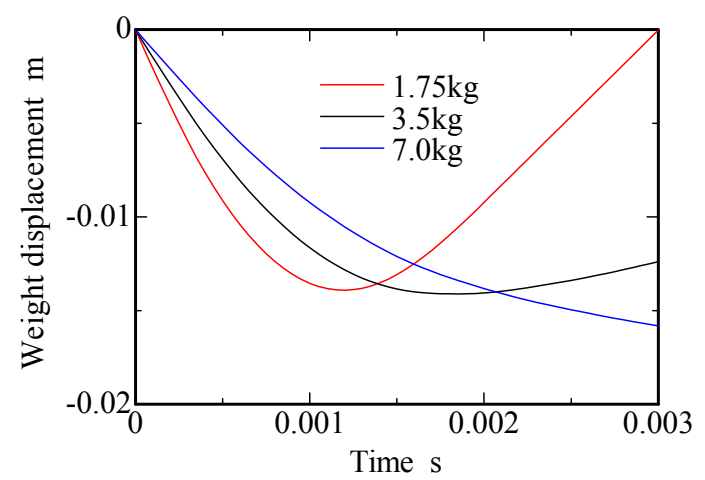

Fig.7(b) Variation of displacement with time

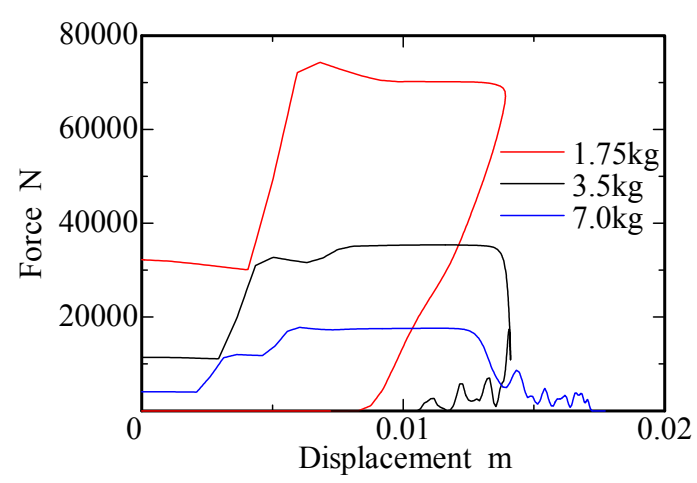

Fig.7(d) Force-displacement diagram

Fig.7 Influence of impact mass (Case3,5,6) 


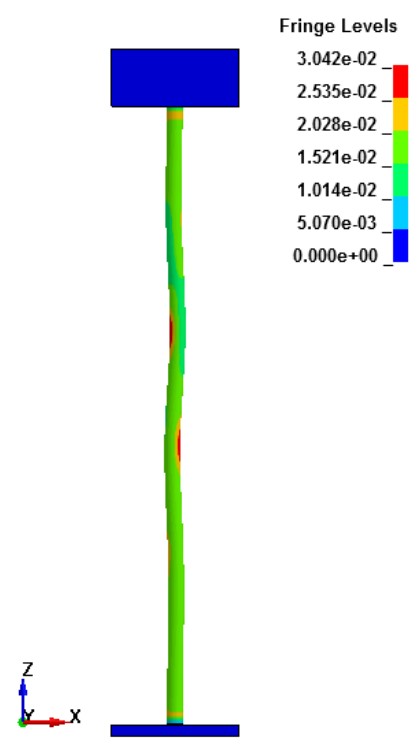

(a) Case $5: 1.75 \mathrm{~kg}$

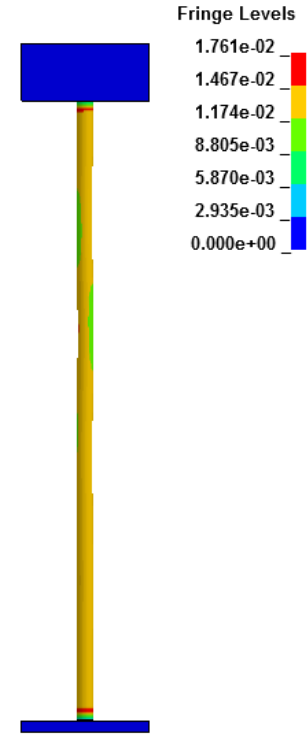

(b) Case6 : $7 \mathrm{~kg}$

Fig.8 Deformation shape and distribution of effective plastic strain $\quad(t=0.0015 \mathrm{~s})$

また，図 8(a)，（b)および図6（b)から分かるように，運動エネルギーが同じでも質量が小さい（すなわち衝 撃速度が速い）ほど被覆管の横方向変位が顕著になり，座屈変形の進行が促進されている事が分かる.

図 7 (b)，(d)より重錘質量が増加するにつれて最大圧縮後の弹性回復量が減少し, $7 \mathrm{~kg}$ の場合は全く回復せず, 荷重減少中も変位が増加し続けていることが分かる。これは, 図 8(a), 図 6(b)に示されるように, 運動エネル ギーが同じで質量が小さい（衝撃速度が速い）ほど打撃が衝撃的になるため，座屈変形が促進されて複数のひず み集中部で曲がりを生じ, 最大変形後にそれらの部分で弾性回復を生じるためであると思われる.これに対して, 質量が増加（衝撃速度が低下）すると，現象は静的圧縮状態に近づき，座屈による局部曲がりは小さく，両端部 のひずみ集中部を除いてほぼ一様なひずみ分布となるため, 最大圧縮後の弾性回復が小さくなるものと考えられ る.

\section{$4 \cdot 3$ 被覆管端部の境界条件の影響（Case $3,7,8$ )}

図 $9(\mathrm{a})$ に衝撃荷重の時間的変化，図 $9(\mathrm{~b})$ に重錘上下方向変位の時間的変化，図 $9(\mathrm{c})$ に吸収エネルギーの時 間的変化，図 $9(\mathrm{~d})$ に荷重一変位線図を示す（重鍾変位は下方を正とした）.

図 10 は $\mathrm{t}=0.0015 \mathrm{~s}$ と $\mathrm{t}=0.005 \mathrm{~s}$ （重錘離脱後）における被覆管変形形状と相当塑性ひずみ分布を示したもので ある. 同図( a ), (b)は被覆管上端面が無拘束の場合 (Case8 : Free), 同図( c) は拘束を与えた場合 (Case3 : Pin およびCase7：Fix）の場合を示している．なお，Pin（Case3）のt=0.0015s は図 6 (b)に既出である.

図 9(a)より衝撃荷重については Case3（Pin）とCase7（Fix）にほとんど差が見られなかった。これは，薄 肉円管とはいえ上端部は点（ピン支持）ではなく面（節点群）で荷重を受け持つためであると思われる．すなわ ち, 解析上 Case 3 では被覆管上端面上の節点は回転自由に設定されているが，端面全体として荷重を受け持つた め各節点に回転は生じなかったものと思われる. 図6(b)からもCase3において被覆管上端面に回転が生じてい ない事が確認される.したがって, Case3（Pin）と Case7（Fix）は同じ結果になったものと考えられる. 一方， Case8（拘束無し）の場合は，拘束あり（Case3,7）の場合に比べて荷重の急落が早期化され，その後の重錘変位 が大きくなっている（図 9(a)，（b))。したがって，図 9(c)，(d)に示されるように，吸収エネルギーおよび荷 重一変位線図に対する境界条件の影響は非常に小さい.

図 9(b)に示されるように, 重錘変位については Case 3,7 の重鍾変位が最大值に達した後に Case 8 との差が生 じ始めている．これは，図10(a)，（b)に示されるように，最大変位後の重錘の上昇に伴って重錘と被覆管上端 面の間の接触力が減少し, 被覆管の曲がりの弾性回復によって, 被覆管が横方向に変位するためである.このた め, 図 10(b),（c)に示されるように, 重錐離脱後の被覆管の変形形状は境界条件によって異なり, 拘束が多い 
Case3 (Pin) および Case7 (Fix) では管の中央部付近での曲がりが大きくなる計算結果であるのに対して, Case8 (Free）のように境界での拘束が少ないほど管上端寄りの位置で曲がりが大きくなることが予測された.

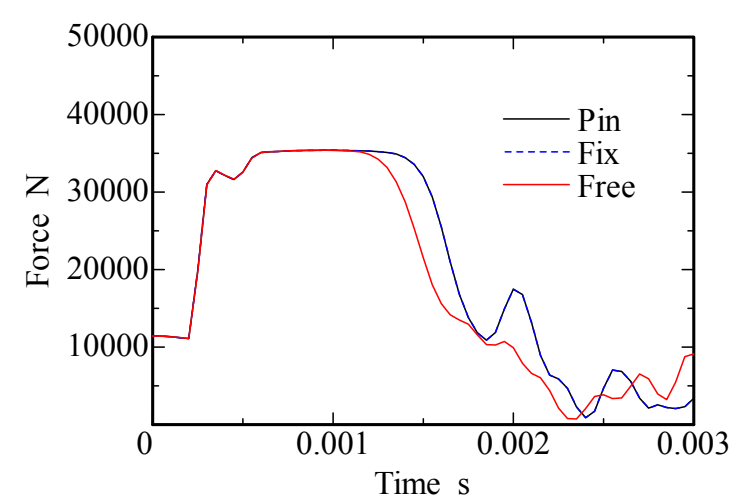

Fig.9(a) Variation of force with time

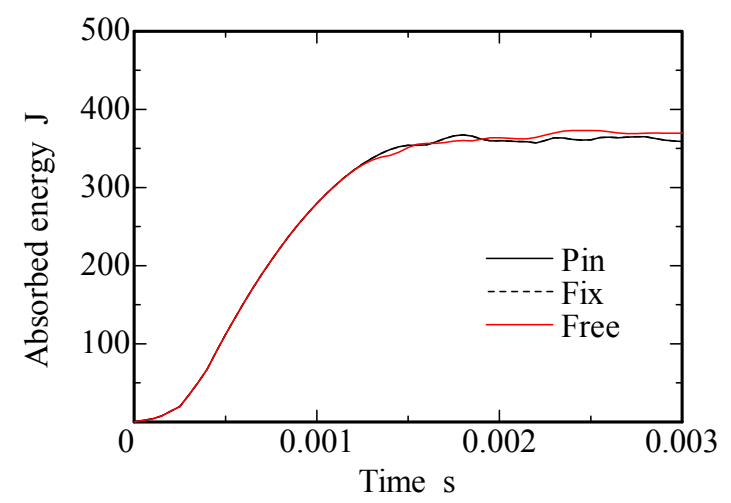

Fig.9(c) Variation of absorbed energy with time

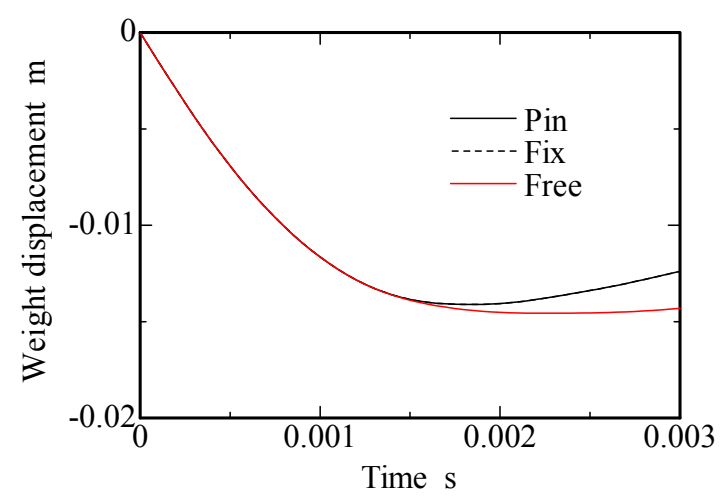

Fig.9(b) Variation of displacement with time

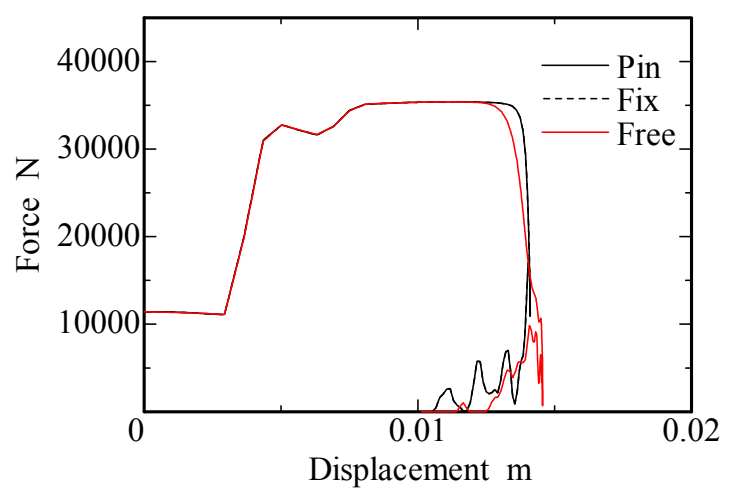

Fig.9(d) Force-displacement diagram

Fig.9 Influence of boundary condition (Case3,7,8)

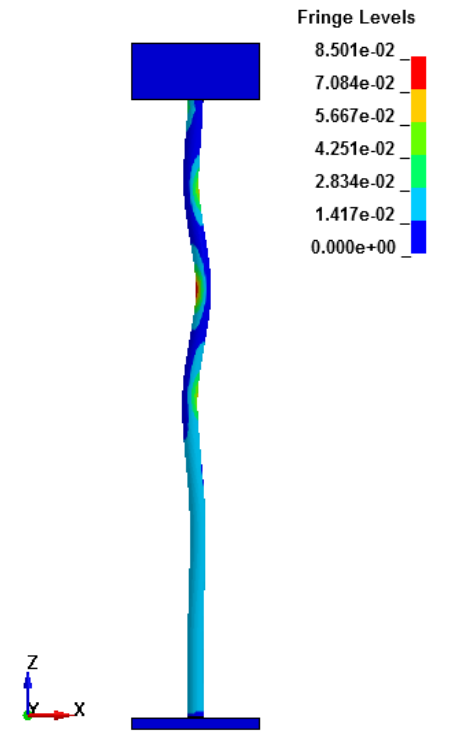

(a) Case 8 :Free $(\mathrm{t}=0.0015 \mathrm{~s})$

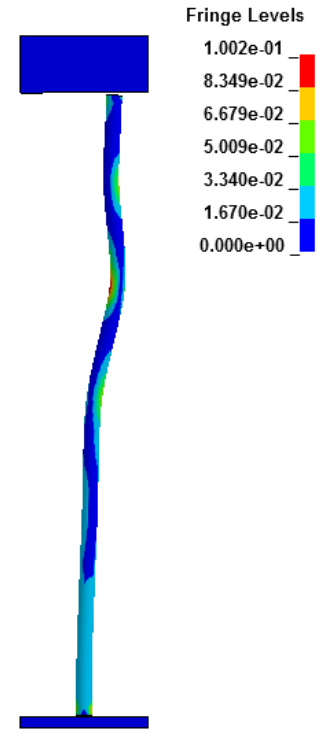

(b) Case 8 :Free $(\mathrm{t}=0.005 \mathrm{~s})$

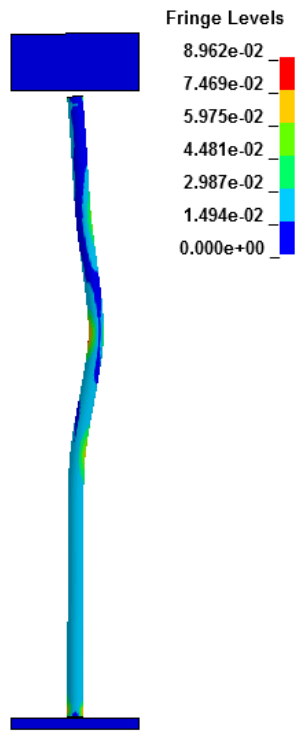

(c) Case3,7 :Pin, Fix $(\mathrm{t}=0.005 \mathrm{~s})$

Fig.10 Deformation shape and distribution of effective plastic strain 
以上より，被覆管端部の境界条件の影響は，変位拘束の有無の影響が主であり，回転の拘束の影響は見られな かった。 上端が無拘束の場合は座屈の発生が早期化され，荷重が早期に急減するが重錘変位が増加するため，吸 収エネルギーへの影響は小さい.しかし，無拘束の場合は被覆管の曲がりの弾性回復によって上端の横方向変位 が生じるため，重錘分離後の被覆管変形形状は境界条件によって大きく異なる.

\section{$4 \cdot 4$ 打撃点偏心量の影響（Case $3,9,10 ）$}

図 11( a )に衝撃荷重の時間的変化，図 11(b)に重鍾上下方向変位の時間的変化，図 11( c)に吸収エネルギーの 時間的変化，図 $11(\mathrm{~d})$ に荷重一変位線図を示す（重錘変位は下方を正とした）.

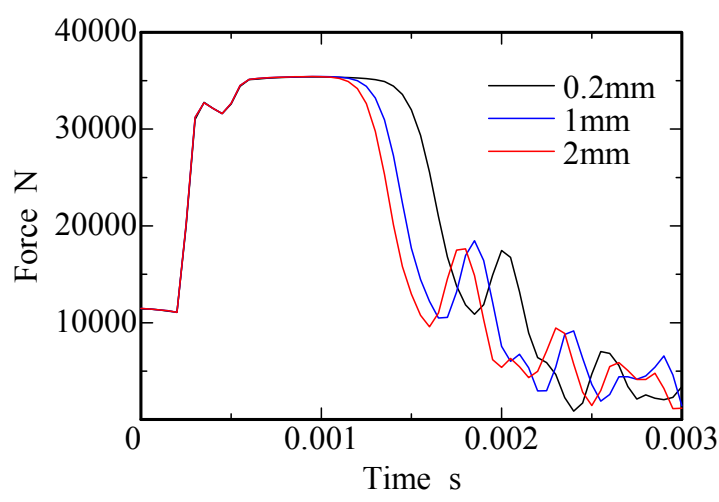

Fig.11(a) Variation of force with time

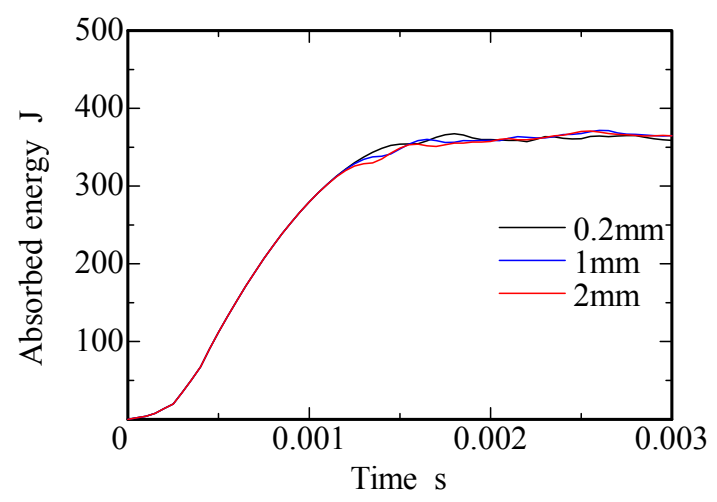

Fig.11(c) Variation of absorbed energy with time

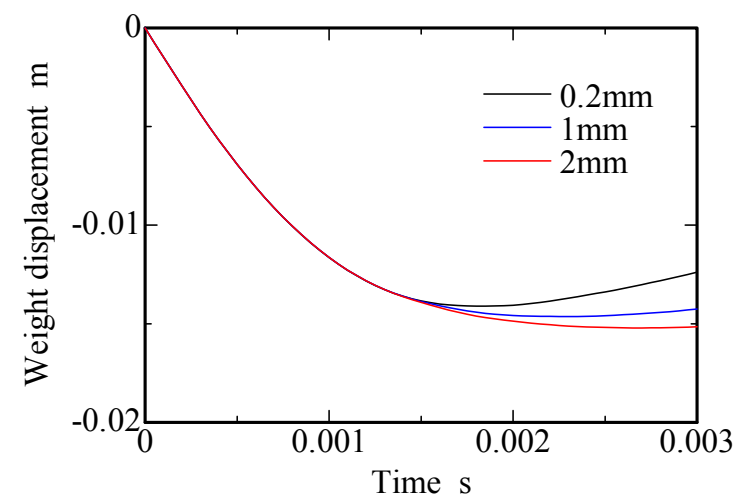

Fig.11(b) Variation of displacement with time

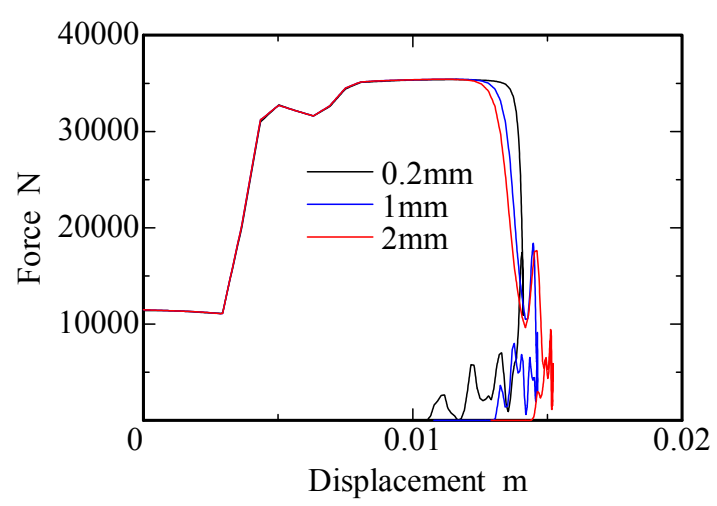

Fig.11(d) Force-displacement diagram

Fig.11 Influence of eccentricity of impact point (Case3,9,10)

図 11( a )に示されるように，初期の応力波伝播から最大荷重に達し，荷重一定で座屈が進行する段階（0.1ms 程度）までは, 打撃点偏心量の影響はみられない. しかし, ずれ量が大きくなるにつれて荷重の急減が早くなり， 座屈変形の進行が早期化する傾向が見られた。これは，打撃点が被覆管の中心からずれることにより，被覆管に 作用する曲げモーメントが大きくなり，座屈の進行が促進されたことによるものと考えられる. 一方，図 11(b)， (d)に示されるように, Case3（偏心量 $0.2 \mathrm{~mm}$ ）では最大変位後に弾性反発を生じているが，偏心量が増加する と弾性反発が少なくなり，重錘の下方への変位が大きくなる．このように，偏心量が増加すると，座屈が早期発 生（荷重が早期減少）するが重錘変位は増加するため, 図 11( c)に示されるように吸収エネルギーには大きな差 は見られない.

以上より, 打撃点の偏心量（～2mm） が増加すると, 座屈の発生が早期化され, 主に被覆管座屈後の荷重およ び重錘変位の時間的変化に影響をおよぼすが，吸収エネルギーへの影響は小さい事が分かる。 


\section{$4 \cdot 5$ 座届荷重の検討}

動的な座屈現象では，巨視的な曲がりが発生する前兆現象として，ほぼ管全長に渡って衝撃力による高応力が 生じ材料の降伏に至る ${ }^{(14)}$. そしてその後に巨視的な曲がりが発生し，荷重が低下寸る．すなわち，巨視的な座屈 が観察される前に最大荷重を経験しているという特徵があり，その点が静的な不安定曲がりの発生に直接対応す るオイラーの座屈荷重とは異なる，そのため，ここでは動的に巨視的な曲がりが生じるときの荷重ではなく，経 験した最大の圧縮荷重を動的座屈荷重と定義する.

表 1 に示した全解析ケースに対して得られた動的座屈荷重（最大荷重）を表 2 にまとめた.

これより動的座屈荷重について以下の事が分かる.

(1)衝撃速度が遅いと最大応力が降伏応力以下となり座屈を生じない.

(2)重鍾質量が大きいほど座屈荷重は減少する.

(3)管端部の境界条件ならびに衝撃位置の偏心量（ 2mm）に依存しない.

Table 2 Maximum load (Dynamic buckling load)

\begin{tabular}{|c|c|c|c|}
\hline & & Case No. & Max. load $(\mathrm{kN})$ \\
\hline \multirow{4}{*}{ Impact velocity } & $5 \mathrm{~m} / \mathrm{s}$ & 1 & 24.4 (no buckling) \\
\cline { 2 - 4 } & $10 \mathrm{~m} / \mathrm{s}$ & 2 & 34.4 \\
\cline { 2 - 4 } & $15 \mathrm{~m} / \mathrm{s}$ & 3 & 35.4 \\
\cline { 2 - 4 } & $20 \mathrm{~m} / \mathrm{s}$ & 4 & 37.1 \\
\hline \multirow{3}{*}{ Impact mass } & $1.75 \mathrm{~kg}$ & 5 & 74.3 \\
\cline { 2 - 4 } & $3.5 \mathrm{~kg}$ & 3 & 35.4 \\
\cline { 2 - 4 } & $7.0 \mathrm{~kg}$ & 6 & 17.8 \\
\hline \multirow{3}{*}{ Boundary condition } & $\mathrm{Pin}$ & 3 & 35.4 \\
\cline { 2 - 4 } & $\mathrm{Fix}$ & 7 & 35.4 \\
\cline { 2 - 4 } & $\mathrm{Free}$ & 8 & 35.4 \\
\hline \multirow{3}{*}{ Eccentricity } & $0.2 \mathrm{~mm}$ & 3 & 35.4 \\
\cline { 2 - 4 } & $1 \mathrm{~mm}$ & 9 & 35.4 \\
\cline { 2 - 4 } & $2 \mathrm{~mm}$ & 10 & 35.4 \\
\hline
\end{tabular}

\section{$4 \cdot 6$ 被覆管の破壊}

表 1 の Case3 について被覆管の破壊挙動を検討寸る. 2 章で述べたように，被覆管材料の破断伸びは数\%程度 と考えられる．よって，ここでは材料の破断ひずみを相当塑性ひずみ $3 \%$ と仮定する. 図 6 (b)に示される Case3 の相当塑性ひずみ分布を見ると，ひずみ集中部で $3 \%$ 以上相当塑性ひずみを生じており，本破壊条件により，

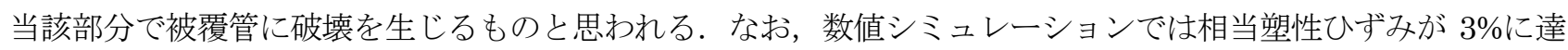
した要素をその時点で消滅させることにより破壊を模擬し，Case3の結果と比較した.

図 $12(\mathrm{a})$ に衝撃荷重の時間的変化，図 12(b)に重鍾上下方向変位の時間的変化，図 $12(\mathrm{c})$ に吸収エネルギーの 時間的変化，図 $12(\mathrm{~d})$ に荷重一変位線図を示寸（重錘変位は下方を正とした）.

図 13(a )，(b)はそれぞれ t=0.0015s，t=0.0016s における被覆管変形形状と相当塑性ひずみ分布を示したもの である。なお，Case3（破壞無し）の場合は，図6（b)に既出である.

図 12(a) （d)に示されるように，初期の応力波伝播から荷重急減時（0.0014s）までは，破壊がなく， Case3 の結果と変わらないが, $\mathrm{t}=0.0015 \mathrm{~s}$ で管側部のひずみ集中部に破壊が生じると, 荷重, 吸収エネルギーは急落し, 重鍾変位に弾性回復が見られなくなった.

図 13(a)に示すように，破壊は $\mathrm{t}=0.0015 \mathrm{~s}$ で管中央部左側部のひずみ集中部で最初に生じた．次に，図 13(b) に示すように, t=0.0016s で管中下部右側部のひずみ集中部で破壊を生じ, 図には示していないが $\mathrm{t}=0.0017 \mathrm{~s}$ で 管下端に破壊を生じ，連続的に 3 カ所で破壊を生じ，被覆管は 4 部分に分離した. 


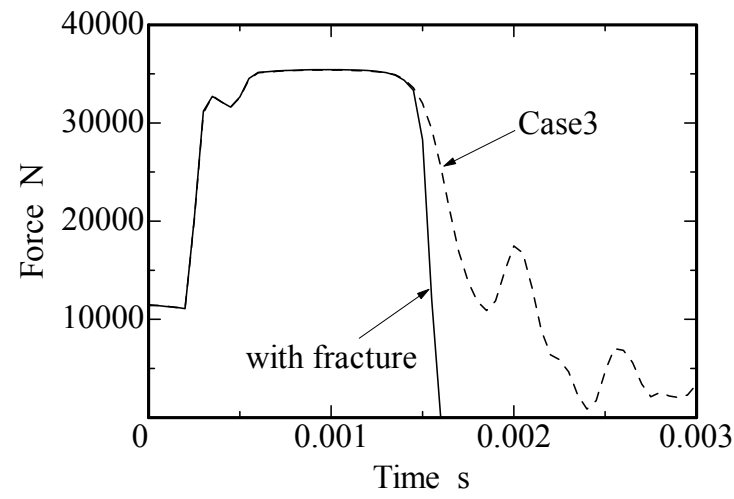

Fig.12(a) Variation of force with time

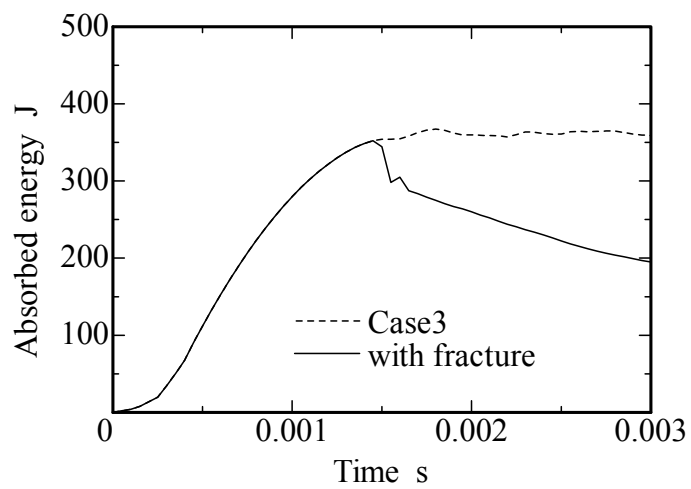

Fig.12(c) Variation of absorbed energy with time

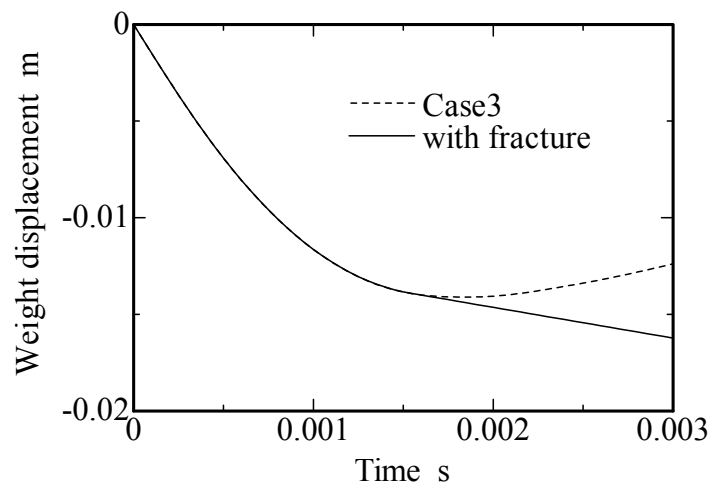

Fig.12(b) Variation of displacement with time

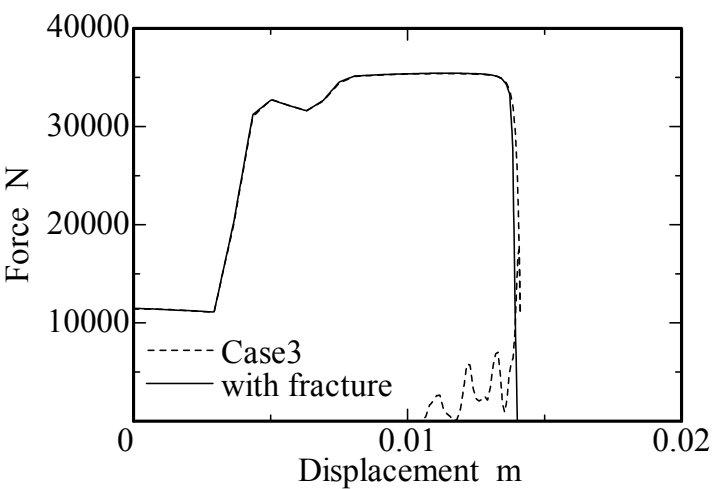

Fig.12(d) Force-displacement diagram

Fig.12 Case of consideration of fracture

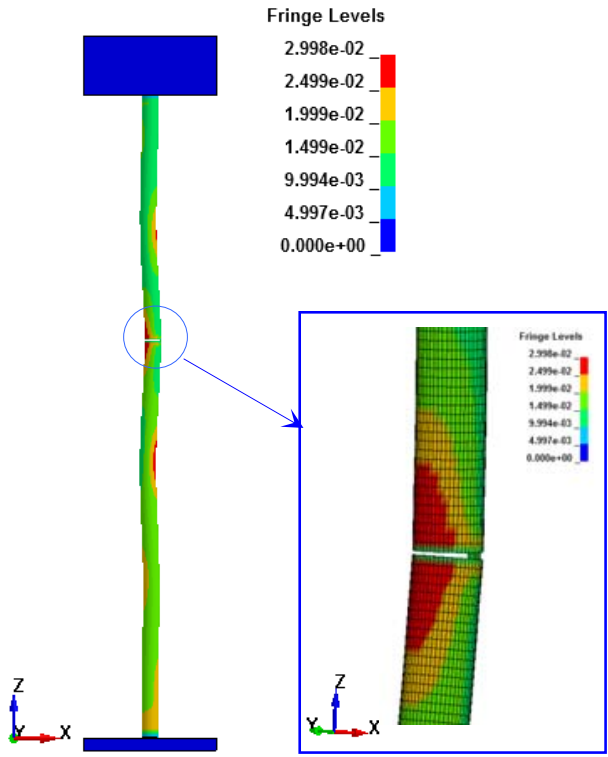

(a) $t=0.0015 \mathrm{~s}$

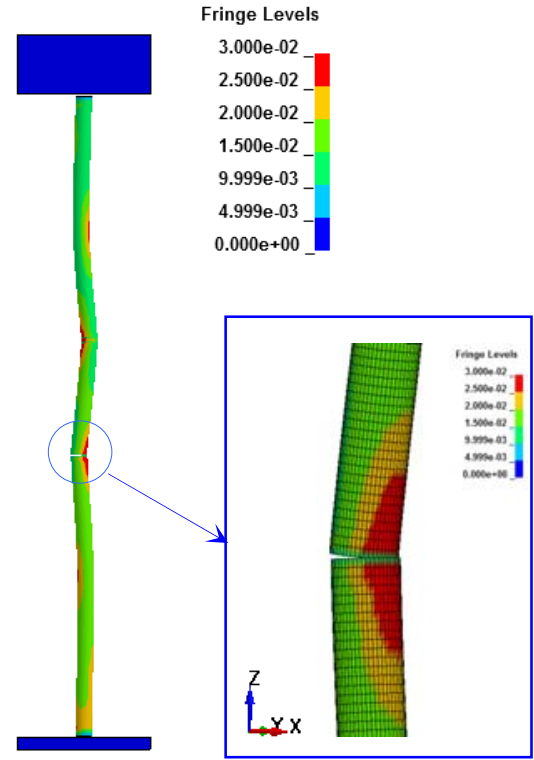

(b) $\mathrm{t}=0.0016 \mathrm{~s}$

Fig.13 Fracture of cladding tube and distribution of effective plastic strain 
ここでは，相当塑性ひずみ $3 \%$ を破壊基準としたので $\mathrm{t}=0.0015 \mathrm{~s}$ で破断を生じたが，破断条件を考慮しなけれ ば，被覆管は時間の経過と共に図 6(b)から図 10( c)のように変化し，座屈による曲がりモード次数が減少する. しかし，図 10( c)におけるひずみ集中部では 9\%近い相当塑性ひずみを生じており，実際の被覆管では被覆管に 破壊が生じているものと思われる，その他の解析ケースについても数\%におよぶ塑性ひずみが発生しており，図 8( a )に示される Case5 の場合は，ひずみ分布の傾向が Case3 と類似していることから，図 13 と類似の破壊形 態を生じると思われる。これに対して，図8（b)に示される Case6 の場合は，ひずみ集中が被覆管上下端部に生 じており，端部から破壊が発生するものと思われる.

\section{5. 結言}

使用済み燃料棒に衝撃荷重が作用したときの燃料棒被覆管の座屈挙動に及ぼす衝撃速度，衝突体質量，端部境 界条件，打撃点偏心量の影響を調べた. また，動的座屈荷重を求め，オイラーの座屈荷重との比較を行った. 計 算には動的有限要素解析コード（LS-DYNA）を用い，高然焼度まで使用された燃料棒（燃料ペレット剛性無し， ジルカロイ -2 製被覆管，外径約 $12.3 \mathrm{~mm}$ ，内径約 $10.6 \mathrm{~mm}$ ，長さ $500 \mathrm{~mm}$ ）に衝撃荷重が作用したときの座屈 挙動の数值解析を行い, 結果を考察した. 本論文で得られた結果を以下に記す.

(1)衝撃速度が速くなるほど最大荷重ならびに吸収エネルギーが増加する。また，応力波の減衰が早く，座屈の 出現（荷重の減少）も早い.

(2)重錘が持つ運動エネルギーが同じなら，重錘質量が小さいほど（衝撃速度が速いほど）最大荷重ならびに重 錘の反発変位は大きい.また, 応力波の減衰が早い.しかし, 衝突後の吸収エネルギーは, 重錘質量が大きい（衝 撃速度が低い) ほうが大きい.

(3)打撃点が被覆管の中心から 0.2-2.0mm の範囲内で偏心しても荷重，曲がり，吸収エネルギーへの影響は少 ない.

(4)打撃点での回転自由および回転固定の境界条件の差異は, 動的座屈荷重および吸収エネルギーにはほとんど 影響を及ぼさない.しかし, 被覆管の曲がり形状は境界条件によって異なり, 変位および回転を拘束した場合 (Pin および Fix）は管の中央部の曲がりが大きくなるのに対して，拘束なしの場合（Free）は打撃点（管上端）寄り の位置で曲がりが大きくなる.

炉内で照射された試験片を用いての実験には種々の困難を伴い，試験条件，試験回数ともに限定されるため， 本論文で示した燃料棒被覆管の座屈挙動に及ぼす各種因子をパラメータとした定量的な評価は，使用済み燃料棒 落下時の健全性評価にとって有用な知見になるものと思われる.なお，本論文では被覆管のみの座屈挙動を取り 扱ったが，今後は然料ペレットを考慮した検討が必要であると考えている.

\section{文献}

（1）有冨正憲，重留義明，蔦澤雄二，上村勝一郎，安部浩，横山武，白井孝治，竹田知幸，大西一成，広瀬誠，吉村英 二，下条純，望月信一，大岩章夫，清水仁，“リサイクル燃料資源の確かな安全備蓄に向けて：使用済燃料中間貯 蔵の現状と対策”，日本原子力学会誌，Vol.48, No.9(2006), pp.637-660.

(2) Ladkany, S. G., "Final report on the waste package project, -The structural performance of the shell and fuel rods of a high level nuclear waste container", DOE/NV/10872-T271-Vol.1, Appendix D (1996).

(3) Bjorkman, G. S., "The Buckling of Fuel Rods under Inertia Loading", Transactions, SMiRT 19, Toronto, August (2007), Paper C03/2.

(4) Adkins, H. E., Koeppel, B. J., and Tang, D. T., "Spent nuclear fuel structural response when subject to an end impact accident", ASME PVP2004, Vol. 483 (2004), pp. 207-214.

(5) WU, Huang-Jau, TSENG, Che-Chung and CHEN Shih-Chung, "A Numerical analysis for a BWR fuel assembly drop event”, Journal of Nuclear Science and Technology, Vol. 43, No. 9 (2006), pp.1068-1073.

(6) Nakatsuka, M., "Mechanical properties of neutron irradiated fuel cladding tubes", Journal of Nuclear Science and Technology, Vol.28, No. 4 (1991), pp.356-368.

(7) Norman, J., Structural Impact, (1997), Cambridge University Press. 
(8) Karagiozova D., Norman, J., "Dynamic effects on buckling and energy absorption of cylindrical shells under axial impact”, Thin-Walled Structures, Vol. 39 (2001), pp.583-610.

(9) Murase, K., Wada, H., "Numerical study on the transition of plastic buckling modes for circular tubes subjected to an axial impact load”, International Journal of Impact Engineering, Vol.30 (2004), pp.1131-1146.

(10) Kenny S., Pegg N., Taheric F., "Finite element investigations on the dynamic plastic buckling of a slender beam subject to axial impact”, International Journal of Impact Engineering, Vol. 27 ,(2002) , pp.179-195.

(11) Hayashi, T., Sano, Y., "Dynamic buckling of Elastic Bars (2nd report, the case of high velocity impact)", Bulletin of the JSME, Vol.15, No.88 (1972), pp. 1176-1184.

(12) Karagiozova D., Marclio A., "Transition from progressive buckling to global bending of circular shells under axial impact_-Part I: Experimental and numerical observations”, International Journal of Solids and Structures, Vol.41, (2004), pp.1565-1580.

(13) Wang B., Lu G., "Mushrooming of circular tubes under dynamic axial loading", Thin-Walled Structures, Vol.40, (2002), pp.167-182.

（14）感本広文，安田隆芳，中司雅文，河村庄造，”衝撃荷重を受ける燃料棒の座屈挙動（材料特性の影響に関する数値 試験)”，日本機械学会論文集 A 編，Vol.77, No.773 (2011), pp.16-26.

(15) Nakatsuka, M., Nagai, M., "Reduction of plastic anisotropy of Zircaloy cladding by neutron irradiation (I)", Journal of Nuclear Science and Technology, Vol.24, No. 10 (1987), pp.832-838.

(16) Nakatsuka, M., Nagai, M., "Reduction of plastic anisotropy of Zircaloy cladding by neutron irradiation (II)", Journal of Nuclear Science and Technology, Vol.24, No. 11 (1987), pp.906-914.

(17) Nakatsuka, M., Uchida, K., Miyazaki, A., Ishii, Y., "Annealing study on neutron irradiation effects in resonance frequencies of Zircaloy plates by EMAR method”, Journal of Nuclear Science and Technology, Vol.44, No. 10 (2007), pp.1285-1294.

(18) Yasuda, T., Nakatsuka, M., Yamashita, K., "Deformation and fracture properties of neutron-irradiated recrystallized Zircaloy-2 cladding under uniaxial tension”, ASTM STP 939 (1987), pp.734-747.

(19) Nakatsuka, M., Une, K., Tokunaga, K., Ohta, T., "Mechanical properties of high burnup BWR fuel cladding tubes under simulated RIA conditions", Proceedings of the 2004 International Meeting on LWR Fuel Performance (2004), Paper 1017.

(20) Nakatsuka, M., Yagnik, S., "Effect of Hydrides on Mechanical Properties and Failure Morphology of BWR Fuel Cladding at Very High Strain Rate", Journal of ASTM International, Vol.8, No.1 (2010), Paper ID JAI102954.

(21) LS-DYNA KEYWORD USER'S MANUAL, Version 971, Livermore Software Technology Corporation (2007).

(22) LS-DYNA THEORY MANUAL, Livermore Software Technology Corporation (2006). 